\title{
MENINGKATKAN PERILAKU ASERTIF SISWA KELAS X SMA KARTIKA III-1 BANYUBIRU MELALUI LAYANAN BIMBINGAN KELOMPOK
}

\author{
Putri Adri Setyowati \\ Alumni Program Studi S1 Bimbingan dan Konseling \\ FKIP Universitas Kristen Satya Wacana \\ Yari Dwikurnaningsih \\ Program Studi S1 Bimbingan dan Konseling \\ FKIP Universitas Kristen Satya Wacana
}

\begin{abstract}
ABSTRAK
Penelitian ini berujuan untuk mengetahui signifikasi peningkatan perilaku asertif melalui layanan bimbingan kelompok di SMA Kartika III-1 Banyubiru. Jenis penelitian ini termasuk penelitian eksperimen dengan desain eksperimen semu. Subyek dalam penelitian ini adalah 12 siswa yang memiliki perilaku asertif rendah. Teknik pengumpulan data menggunakan alat ukur berupa angket perilaku asertif Alberti \& Emmons yang dimodifikasi oleh Siampa (2011). Analisis data untuk melihat peningkatan perilaku asertif dua kelompok digunakan Two Independent Sample Test (Mann-Whitney Ttest) yang diolah menggunakan program SPSS for Windows versi 11.5. Hasil analisis diperoleh $p=$ Asymp Sig 0,005<0,050, artinya ada perbedaan yang signifikan perilaku asertif antara kelompok eksperimen dan kelompok kontrol, setelah kelompok eksperimen diberi layanan bimbingan kelompok. Berdasarkan rata-rata skor perilaku asertif sebelum dan sesudah eksperimen menunjukkan adanya peningkatan, mean sebelum eksperimen 6,00 dan setelah eksperimen menjadi 9,42 . Berdasarkan hasil analisa data tersebut, dapat disimpulkan bahwa layanan bimbingan kelompok dapat meningkatkan perilaku asertif siswa kelas X SMA Kartika III-1 Banyubiru.
\end{abstract}

Kata kunci: Perilaku Asertif, Layanan Bimbingan Kelompok.

\section{PENDAHULUAN}

\section{Latar Belakang Masalah}

Dalam dunia pergaulan maupun dalam proses belajar saat ini, siswa dituntut untuk dapat aktif dalam mengemukakan pendapat, saran dan keinginan yang dimilikinya secara langsung, jujur dan terbuka. Untuk mengatasi masalah dalam mengemukakan pendapat tersebut, siswa dituntut untuk mengembangkan perilaku asertif secara efektif dalam interaksi sosial di dalam lingkungannya, terutama dalam interaksi sosialnya dengan teman sebayanya. Perilaku asertif merupakan sebuah kemampuan untuk mempromosikan kesetaraan dalam hubungan manusia, yang memungkinkan individu-individu untuk bertindak menurut kepentingan individu sendiri, untuk membela diri sendiri tanpa kecemasan yang tidak semestinya, untuk mengekspresikan perasaan dengan jujur dan nyaman, untuk menerapkan hak-hak pribadi individu tanpa menyangkal hak-hak orang lain. (Alberti \& Emmons).

Penelitian yang dilakukan oleh Figraha (2012) dengan judul Upaya Peningkatan 
Sikap Asertif Melalui Sosiodrama pada Siswa Kelas X.1 Administrasi Perkantoran SMK Sudirman 1 Wonogiri Tahun Ajaran 2011/2012, menunjukkan adanya peningkatan perilaku asertif setelah dilakukan layanan bimbingan kelompok yang berupa teknik sosiodrama, yang semula 72,5 persen menjadi 77,3 persen atau sudah masuk pada persentase baik. Hal yang tidak jauh berbeda adalah hasil penelitian Astutik (2005) dengan judul efektifitas layanan bimbingan kelompok dalam meningkatkan keterbukaan diri siswa kelas II SMP Negeri 11 Semarang Tahun Pelajaran 2005/2006. Hasil penelitiannya menunjukkan siswa sebelum mendapat layanan bimbingan kelompok memiliki keterbukaan diri dengan skor rata-rata 2,28, setelah mendapat layanan bimbingan kelompok memiliki skor rata-rata 3,25, sehingga dapat disimpulkan bahwa layanan bimbingan kelompok efektif dapat meningkatkan keterbukaan diri siswa.

Hasil penelitian pendahuluan terhadap siswa kelas X SMA Kartika III-1 Banyubiru, menunjukkan ada 1 siswa yang memiliki perilaku asertif sangat rendah, 11 siswa memiliki perilaku asertif pada kategori rendah, 13 siswa berada ada kategori sedang dan hanya 11 siswa berada pada kategori tinggi. Perilaku asertif sangat penting untuk dimiliki oleh siswa agar ia mampu untuk berinteraksi dengan baik dalam lingkungannya. Dalam menolong siswa yang memiliki perilaku asertif rendah, peneliti memberi layanan bimbingan kelompok. Layanan bimbingan kelompok di sekolah merupakan bagian program layanan bimbingan konseling yang tergolong ke dalam komponen pelayanan dasar, yaitu proses pemberian bantuan kepada seluruh siswa. Layanan bimbingan kelompok dimaksudkan untuk mencegah berkembangya masalah atau kesulitan pada diri konseli (Nurihsan,2005).
Sehubungan dengan uraian latar belakang di atas, peneliti tertarik untuk mengadakan penelitian yang berjudul "Meningkatkan Perilaku Asertif pada Siswa Kelas X SMA Kartika III-1 Banyubiru melalui Layanan Bimbingan Kelompok“.

\section{Rumusan Masalah}

Apakah layanan bimbingan kelompok secara signifikan dapat meningkatkan perilaku asertif siswa kelas X SMA Kartika III-1 Banyubiru?

\section{Tujuan Penelitian}

Untuk mengetahui layanan bimbingan kelompok secara signifikan dapat meningkatkan perilaku asertif siswa kelas X SMA Kartika III-1 Banyubiru.

\section{KAJIAN TEORI}

\section{Perilaku Asertif}

Menurut Smith (dalam Rakos, 1991) menyatakan bahwa perilaku asertif merupakan hak setiap individu untuk menentukan sikap, pemikiran dan emosi yang dilandasi rasa tanggung jawab atas segala hasil serta akibat tersebut bagi individu itu sendiri. Gunarsa (1992) menyatakan bahwa perilaku asertif adalah perilaku antar pribadi (interpersonal behaviour) yang melibatkan aspek kejujuran, keterbukaan pikiran dan perasaan. Perilaku asertif ini ditandai dengan adanya kesesuaian sosial dan seseorang yang mampu berperilaku asertif akan mempertimbangkan perasaan dan kesejahteraan orang lain. Selain itu, kemampuan dalam perilaku asertif menunjukkan adanya kemampuan untuk menyelesaikan diri dalam hubungan antar pribadi.

Lazarus (dalam Rakos, 1991) adalah tokoh yang pertama sekali mendefinisikan perilaku asertif, yang mengatakan bahwa perilaku asertif adalah cara individu dalam 
memberikan respon dalam situasi sosial, yang berarti sebagai kemampuan individu untuk mengatakan tidak, kemampuan untuk menanyakan dan meminta sesuatu, kemampuan untuk mengungkapkan perasaan positif ataupun negatif, serta kemampuan untuk mengawali kemudian melanjutkan serta mengakhiri percakapan.

Master dan Rim (dalam Rakos, 1991) mengatakan bahwa perilaku asertif merupakan perilaku interpersonal antar pribadi yang melibatkan kejujuran dengan pernyataan relatif dan pikiran dan perasaan secara tepat dalam situasi sosial dimana perasaan dan pikiran orang lain ikut dipertimbangkan. Kesemua definisi ini menitik-beratkan pada ungkapan emosi sebagai faktor utama dalam perilaku asertif. Corey (2007) mengatakan bahwa perilaku asertif adalah ekspresi langsung, jujur, dan pada tempatnya dari pikiran, perasaan, kebutuhan atau hak-hak seseorang tanpa kecemasan yang beralasan.

Sedangkan menurut Alberti dan Emmons (dalam Siampa, 2011) perilaku asertif adalah sebuah kemampuan untuk mempromosikan kesetaraan dalam hubungan manusia, yang memungkinkan individuindividu untuk bertindak menurut kepentingan individu sendiri, untuk membela diri sendiri tanpa kecemasan yang tidak semestinya, untuk mengekspresikan perasaan dengan jujur dan nyaman, untuk menerapkan hakhak pribadi individu tanpa menyangkal hakhak orang lain.

Berdasarkan uraian di atas dapat disimpulkan bahwa perilaku asertif adalah perilaku antar pribadi yang menyangkut ekspresi yang tepat, jujur, terbuka, mempunyai sikap yang tegas, positif dan mampu bersikap netral serta dapat mengutarakan akan sesuatu objektif tanpa menyinggung perasaan orang lain.

\section{Aspek-aspek Perilaku Asertif}

Alberti dan Emmons (dalam Siampa, 2011) menyebutkan ada sepuluh pokok kunci yang merupakan aspek-aspek yang harus ada pada setiap perilaku asertif yang dimuncul-kan oleh seseorang antara lain sebagai berikut:

1. Pengungkapan diri yang baik kepada orang lain. Dalam hal ini yang dimaksud adalah mampu untuk mengkomunikasikan apa yang dirasakan, diinginkan dan dipikirkan kepada orang lain.

2. Menghormati orang lain dan tidak mengganggu hak orang lain, dalam hal ini yang dimaksud adalah dalam bersikap dengan orang lain.

3. Mampu secara jujur dan terbuka menyatakan kebutuhan, perasaan dan pikiran dengan apa adanya, dalam hal ini yang dimaksud adalah dalam berkomunikasi dengan orang lain.

4. Langsung, yang berarti mengekspresikan diri tanpa berbelit-belit dan dapat terfokus dengan benar berkomunikasi maupun bertindak.

5. Tidak membeda-bedakan orang dan menguntungkan semua pihak.

6. Verbal, termasuk isi pesan (perasaan, hakhak, fakta, pendapat-pendapat, permintaanpermintaan dan batasan-batasan). Dalam hal ini yang dimaksud adalah dalam berkomunikasi.

7. Nonverbal, termasuk gaya dan pesan (kontak mata, suara, postur, ekspresi muka, gesture, jarak, waktu, kelancaran dan mendengarkan). Dalam hal ini yang dimaksud adalah berupa tindakan atau sikap terhadap orang lain.

8. Bukan suatu yang universal.

9. Bertanggung jawab secara sosial terhadap pikiran, perasaan dan perilakunya.

10. Perilaku asertif merupakan suatu hal yang dipelajari bukan suatu hal yang dibawa sejak lahir.

\section{Bimbingan Kelompok}

Sukardi (2008) layanan bimbingan kelompok adalah layanan bimbingan yang memungkinkan sejumlah peserta didik secara bersama-sama memperoleh berbagai bahan dari narasumber tertentu (terutama dari pembimbing/konselor). 
Nurihsan (2005) layanan bimbingan kelompok adalah layanan yang dimaksudkan untuk memungkinkan klien/siswa secara bersama-sama memperoleh berbagai bahan dari narasumber yang bermanfaat untuk kehidupan sehari-hari. Bahan yang dimaksudkan adalah bahan yang digunakan untuk mengambil keputusan.

Winkel \& Sri Hastuti (2004) layanan bimbingan kelompok adalah kegiatan kelompok diskusi yang menunjang perkembangan pribadi dan perkembangan sosial masingmasing individu-individu dalam kelompok, serta meningkatkan mutu kerja sama dalam kelompok guna aneka tujuan yang bermakna bagi para partisipan.

Dari pengertian layanan bimbingan kelompok di atas, maka dapat disimpulkan bahwa bimbingan kelompok adalah suatu proses pemberian bantuan kepada individu/ layanan bimbingan yang diberikan oleh narasumber dalam kegiatan kelompok yang menunjang perkembangan pribadi dan perkembangan sosial masing-masing individu dalam kelompok guna mencapai tujuan untuk mengambil keputusan dalam kehidupan sehari-hari.

Bimbingan kelompok memiliki banyak manfaat. Menurut Winkel \& Sri Hastuti (2004) manfaat layanan bimbingan kelompok:

1. Mendapat kesempatan untuk berkontak dengan banyak siswa, dengan memberikan layanan bimbingan kelompok dapat bertemu dengan banyak siswa dan dapat mengerti perkembangan siswa.

2. Memberikan informasi yang dibutuhkan oleh siswa, dengan berkontak dengan banyak siswa, dapat mengetahui yang dibutuhkan oleh siswa sehingga kita dapat memberikan informasi.

3. Siswa dapat menyadari tantangan yang akan dihadapi, setelah pemberian informasi.

4. Siswa dapat menerima dirinya setelah menyadari bahwa teman-temannya sering menghadapi persoalan, kesulitan dan tantangan yang kerap kali sama dan lebih berani mengemu- kakan pandangannya sendiri bila berada dalam kelompok, dalam hal ini yang dimaksud lebih terbuka dalam berkomunikasi.

5. Diberikan kesempatan untuk mendiskusikan sesuatu bersama.

6. Lebih bersedia menerima suatu pandangan atau pendapat bila dikemukakan oleh seorang teman daripada yang dikemukakan oleh seorang konselor.

Dari manfaat layanan bimbingan kelompok tersebut dapat disimpulkan bahwa manfaat dari layanan bimbingan kelompok adalah kesempatan berkontak dengan siswa dari berkontak dengan siswa dapat memberikan informasi yang dibutuhkan siswa, dari informasi yang diberikan siswa dapat menyadari tantangan yang akan dihadapi, siswa dapat berpendapat secara terbuka maupun pandangan yang luas akan suatu hal yang dibicarakan, dari kegiatan-kegiatan yang telah dilaksanakan dalam kelompok siswa dapat menyusun program-program kegiatan untuk mewujudkan penolakan terhadap yang buruk dan dukungan terhadap yang baik serta dapat melaksanakan kegiatan secara nyata.

Bimbingan kelompok berlangsung melalui empat tahap. Menurut Prayitno (1995), tahap-tahap bimbingan kelompok adalah sebagai berikut tahap pembentukan, tahap peralihan, tahap kegiatan dan tahap pengakhiran. Tahap pertama, yaitu tahap pembentukan yang merupakan tahap pengenalan, tahap pelibatan diri atau tahap memasukkan diri ke dalam kehidupan suatu kelompok. Pada tahap ini pada umumnya para anggota saling memperkenalkan diri dan juga mengungkapkan tujuan ataupun harapan-harapan masingmasing anggota. Pemimpin kelompok menjelaskan cara-cara dan asas-asas kegiatan bimbingan kelompok. Dalam tahap pembentukan biasanya diberikan ice breaking untuk lebih mengakrabkan masing-masing anggota dan menciptakan suasana yang nyaman.

Tahap kedua merupakan tahap peralih- 
an. Pada tahap ini pemimpin kelompok menjelaskan apa yang akan dilakukan oleh anggota kelompok pada tahap kegiatan lebih lanjut dalam kegiatan kelompok. Pemimpin kelompok menjelaskan peranan anggota kelompok dalam kegiatan, kemudian menawarkan atau mengamati apakah para anggota sudah siap menjalani kegiatan pada tahap selanjutnya. Dalam tahap ini pemimpin kelompok mampu menerima suasana yang ada secara sabar dan terbuka. Tahap kedua merupakan "jembatan" antara tahap pertama dan ketiga. Dalam hal ini pemimpin kelompok membawa para anggota meniti jembatan tersebut dengan selamat. Bila perlu, beberapa hal pokok yang telah diuraikan pada tahap pertama seperti tujuan dan asas-asas kegiatan kelompok ditegaskan dan dimantapkan kembali, sehingga anggota kelompok telah siap melaksanakan tahap bimbingan kelompok selanjutnya.

Tahap ketiga adalah tahap kegiatan. Tahap ini merupakan inti dari layanan bimbingan kelompok dimana masing-masing anggota kelompok saling berinteraksi memberikan tanggapan. Namun, kelangsung-an kegiatan kelompok pada tahap ini amat tergantung pada hasil dari dua tahap sebelumnya. Jika dua tahap sebelumnya berhasil dengan baik, maka tahap ketiga itu akan berhasil dengan lancar.

Tahap terakhir yaitu tahap pengakhiran. Pada tahap ini merupakan tahap berhentinya kegiatan. Dalam pengakhiran ini terdapat kesepakatan kelompok apakah kelompok akan melanjutkan kegiatan dan bertemu kembali serta berapa kali kelompok itu bertemu. Dengan kata lain kelompok yang menetapkan sendiri kapan kelompok itu akan melakukan kegiatan. Dapat disebutkan kegiatan-kegiatan yang perlu dilakukan pada tahap ini adalah: (1) penyampaian pengakhiran kegiatan oleh pemimpin kelompok;
(2) pengungkapan kesan-kesan dari anggota kelompok; (3) penyampaian tanggapantanggapan dari masing-masing anggota; (4) pembahasan kegiatan lanjutan; (5) penutup.

\section{METODE PENELITIAN}

Jenis penelitian yang digunakan adalah eksperimen, dengan desain eksperimen semu. Penelitian eksperimen ini menggunakan dua kelompok yaitu kelompok eksperimen dan kelompok kontrol. Kelompok eksperimen adalah kelompok yang akan diberi perlakuan bimbingan kelompok dalam rangka meningkatkan perilaku asertif siswa. Sedangkan kelompok kontrol adalah kelompok yang tidak diberi perlakuan sama sekali.

Prosedur eksperimen meliputi: (1) uji homogenitas kedua kelompok; (2) pemberian pretest kepada kedua kelompok untuk mengetahui tingkat perilaku asertif siswa sebelum eksperimen; (3) pemberian posttest kepada kedua kelompok untuk mengetahui tingkat perilaku asertif siswa setelah eksperimen. Model yang digunakan dalam penelitian ini digambarkan sebagai berikut:

$$
\text { Kelompok: Pretest Treatment Postest }
$$

\begin{tabular}{ccc}
$\mathrm{T} 1$ & $\mathrm{X}$ & $\mathrm{T} 2$ \\
$\mathrm{~T} 1$ & - & $\mathrm{T} 2$ \\
\hline
\end{tabular}

Gambar 1 Desain Eksperimen

Penjelasan dari gambar tersebut sebagai berikut: (1) T1 adalah Tes awal/pretest; (2) T2 yaitu Tes akhir/posttest; (3) X adalah Perlakuan/Treatment (layanan bimbingan kelompok).

Variabel penelitian pada dasarnya adalah segala sesuatu yang berbentuk apa saja yang ditetapkan oleh peneliti untuk dipelajari sehingga diperoleh informasi tentang hal tersebut, kemudian ditarik kesimpulannya. Dalam penelitian ini terdapat dua variabel yaitu variabel bebas (variabel independen) yaitu layanan bimbingan kelompok 
dan variabel terikat (variabel dependen) yaitu perilaku asertif.

Subyek yang diambil dalam penelitian ini adalah 12 siswa kelas X SMA Kartika III-1 Banyubiru. Subjek diambil melalui hasil data dari penyebaran skala perilaku asertif dan diketahui siswa yang memiliki perilaku asertif rendah dan sangat rendah berjumlah 12 siswa. Selanjutnya dibagi menjadi 2, 1 kelompok yang terdiri dari 6 siswa sebagai kelompok kontrol dan 1 kelompok terdiri dari 6 siswa sebagai kelompok eksperimen.

Teknik pengumpulan data menggunakan skala yaitu skala perilaku asertif dengan jumlah 45 item. Item pertanyaan berupa favourable dan unfavourable. Peneliti memodifikasi dari angket yang disusun oleh Siampa (2011) yang mengacu pada aspekaspek perilaku asertif dari Alberti \& Emmons.

Teknik analisa data untuk mengetahui perbedaan perilaku asertif kelompok eksperimen dan kelompok kontrol menggunakan teknik uji Mann Whitney dan untuk pengolahannya menggunakan bantuan program komputer SPSS (Statistical for Social Science) versi 11.5 for Windows.

\section{HASIL PENELITIAN DAN PEMBAHASAN}

\section{Pelaksanaan Penelitian}

1. Tes Awal (pre test)

Pre test dilaksanakan pada tanggal 30 dan 31 Agustus 2013, dengan tujuan untuk mengetahui kondisi awal siswa dan menguji homogenitas kedua kelompok. Berdasarkan hasil uji homogenitas bahwa dari kelompok eksperimen dan kontrol yaitu Asymp. Sig. (2-tailed) 0.630>0.050 dapat disimpulkan bahwa tidak terdapat perbedaan yang signifikan antara kelompok eksperimen dan kelompok kontrol, sehingga kedua kelompok tersebut dapat digunakan sebagai subyek uji coba.

Tabel 1 Uji Homogenitas Pre Test kelompok eksperimen dan kelompok kontrol dengan Mann Whitney

\begin{tabular}{ccccc}
\multicolumn{4}{c}{ Ranks } & \\
\hline KELOMPOK & $\mathrm{N}$ & $\begin{array}{c}\text { Mean } \\
\text { Rank }\end{array}$ & $\begin{array}{c}\text { Sum of } \\
\text { Ranks }\end{array}$ \\
\hline PRETEST Eksperimen & 6 & 6,00 & 36,00 \\
Kontrol & 6 & 7,00 & 42,00 \\
\hline Total & 12 & & \\
\hline
\end{tabular}

\section{Test Statistics $(\mathbf{b})$}

\begin{tabular}{lr}
\hline & PRETEST \\
\hline Mann-Whitney U & 15,000 \\
Wilcoxon W & 36,000 \\
Z &,- 482 \\
Asymp. Sig. (2-tailed) &, 630 \\
Exact Sig. [2*(1-tailed Sig.)] &, $699(a)$ \\
\hline
\end{tabular}

2. Perlakuan (treatment)

Treatment diberikan sesuai dengan rancangan layanan bimbingan kelompok yang sudah dibuat peneliti dan dilaksanakan sesuai kesepakatan antara peneliti dengan kelompok eksperimen. Treatment merupakan pemberian layanan bimbingan kelompok kepada kelompok eksperimen sebanyak 8 kali. Materi layanan bimbingan kelompok disesuaikan dengan indikator-indikator perilaku asertif, yaitu: berusaha mencapai tujuan, pengungkapan diri, menghormati dan tidak mengganggu hak orang lain, jujur dan terbuka, langsung, tidak membeda-bedakan orang dan menguntungkan semua pihak, bertanggung jawab secara sosial, penolakan, menghargai pujian dan menerima kritikan dari orang lain, menyapa dan memberi salam kepada orang lain. 
3 Tes Akhir (Post-Test)

Post-test diberikan kepada kelompok eksperimen dan kelompok kontrol dengan menggunakan skala perilaku asertif. Tujuan post-test adalah untuk mengetahui tingkat perilaku asertif siswa setelah kelompok eksperimen diberi perlakuan.

\section{Uji Hipotesis}

Dalam penelitian ini hipotesis yang peneliti ajukan adalah " Ada peningkatan yang signifikan perilaku asertif melalui layanan bimbingan kelompok di SMA Kartika III1 Banyubiru" atau dengan kata lain "Layanan bimbingan kelompok dapat meningkatkan perilaku asertif siswa kelas X SMA Kartika III-1 Banyubiru".

\section{Hasil Penelitian dan Pembahasan}

Setelah kelompok eksperimen diberi layanan bimbingan kelompok sebanyak 8 kali, peneliti melaksanakan post-test kepada kelompok eksperimen dan kelompok kontrol. Hasil post-test kemudian diolah menggunakan teknik analisis Mann-whitney Test untuk mengetahui perbedaan kedua kelompok tersebut. Hasil ujibeda kedua kelompok dipaparkan pada tabel 2.

Tabel 2 Ujibeda Post Test kelompok kontrol dan kelompok eksperimen dengan Mann Whitney

\begin{tabular}{llccc}
\hline KELOMPOK & $\mathrm{N}$ & $\begin{array}{c}\text { Mean } \\
\text { Rank }\end{array}$ & $\begin{array}{c}\text { Sum of } \\
\text { Ranks }\end{array}$ \\
\hline PRETEST & Eksperimen & 6 & 9,42 & 56,50 \\
& Kontrol & 6 & 3,58 & 21,50 \\
\hline & Total & 12 & & \\
\hline
\end{tabular}

\section{Test Statistics(b)}

\begin{tabular}{lr}
\hline & PRETEST \\
\hline Mann-Whitney U &, 500 \\
Wilcoxon W & 21,500 \\
Z & $-2,817$ \\
Asymp. Sig. (2-tailed) &, 005 \\
Exact Sig. [2*(1-tailed Sig.)] &, $002(\mathrm{a})$ \\
\hline
\end{tabular}

Berdasarkan tabel 2 dapat dilihat bahwa mean rank pretest pada kelompok eksperimen sebesar 6,00 sedangkan mean rank post-test sebesar 9,42. Ada peningkatan skor rata-rata kelompok eksperimen sebesar 3,42. Hasil ujibeda kelompok eksperimen dan kelompok kontrol dengan menggunakan Mann Whitney menghasilkan skor $\mathrm{Z}=-2,817$ dengan Asymp. Sig. (2-tailed) 0,005<0,050 yang berarti ada perbedaan yang signifikan pada kedua kelompok tersebut.

Berdasarkan hasil analisis data tersebut, dapat diketahui bahwa layanan bimbingan kelompok dapat meningkatkan perilaku asertif siswa. Dengan demikian, hipotesis penelitian yang berbunyi "layanan bimbingan kelompok dapat meningkatkan perilaku asertif siswa SMA Kartika III-1 Banyubiru", diterima.

Dari hasil analisis yang telah dilakukan, terdapat peningkatan perilaku asertif antara kelompok eksperimen dan kelompok kontrol setelah kelompok eksperimen diberi layanan bimbingan kelompok. Hasil ini dapat dilihat dari uji Mann Whitney posttest antara kelompok eksperimen dan kelompok kontrol diperoleh hasil yaitu Asymp. Sign. 2-tailed sebesar 0,005<0,050 yang artinya ada peningkatan yang signifikan antara kelompok eksperimen dan kelompok kontrol.

Perilaku asertif siswa bisa dibentuk atau ditingkatkan, karena perilaku asertif tidak dibawa sejak lahir, namun dapat dipengaruhi oleh factor lingkungan. Seperti yang dikemukakan oleh Rakos (1991) bahwa ada banyak faktor yang mempengaruhi perilaku asertif. Menurut Rakos, faktor-faktor yang mempengaruhi perilaku asertif adalah pola asuh orang tua, jenis kelamin dan kebudayaan. Pola asuh orang tua yang demokratis dan memberikan kebebasan untuk mengekspresikan diri akan menciptakan perilaku asertif, sebab pola asuh yang demokratis akan 
membuat anak memiliki rasa percaya diri. Kebudayaan merupakan salah satu faktor yang berpengaruh terhadap terbentuknya sikap asertif. Dengan demikian, perilaku asertif dapat diubah melalui lingkungan, salah satunya adalah melalui bimbingan kelompok.

Hasil penelitian ini membuktikan bahwa layanan bimbingan kelompok dapat meningkatkan perilaku asertif siswa. Dengan demikian bimbingan kelompok memberikan manfaat yang positif kepada siswa dan dapat mencapai tujuan yang diinginkan. Hal ini sejalan dengan apa yang dikemukakan oleh Winkel \& Sri Hastuti (2004) tentang manfaat bimbingan kelompok, yaitu siswa mendapat kesempatan untuk berkontak dengan banyak siswa, dapat menerima dirinya setelah menyadari bahwa teman-temannya sering menghadapi persoalan, kesulitan dan tantangan yang kerap kali sama dan lebih berani mengemukakan pandangannya sendiri bila berada dalam kelompok, dalam hal ini yang dimaksud lebih terbuka dalam berkomunikasi. Demikian pula yang dikemukakan oleh Bennet (dalam Romlah, 2001) tujuan layanan bimbingan kelompok adalah Memberi kesempatan pada siswa belajar hal-hal penting yang berguna bagi pengarahan dirinya yang berkaitan dengan masalah pendidikan, pekerjaan, pribadi dan sosial.

Berdasarkan hasil pengamatan yang peneliti lakukan kepada kelompok eksperimen selama proses layanan bimbingan kelompok berlangsung adalah kelompok eksperimen bisa mengikuti kegiatan dan memperhatikan materi dengan baik, penuh antusias, perhatian, mau merespon dengan baik, mau berpartisipasi dalam kegiatan layanan bimbingan kelompok sehingga berjalan dengan lancar.

Hasil temuan dalam penelitian ini mendukung hasil penelitian yang dilakukan oleh Figraha (2012) dengan judul Upaya Peningkatan Sikap Asertif Melalui Sosiodrama pada Siswa Kelas X.1 Administrasi Perkantoran SMK Sudirman 1 Wonogiri Tahun Ajaran 2011/2012, menunjukkan adanya peningkatan perilaku asertif setelah dilakukan layanan bimbingan kelompok yang berupa teknik sosiodrama. Demikian juga penelitian Astutik (2005) dengan judul efektifitas layanan bimbingan kelompok dalam meningkatkan keterbukaan diri siswa kelas II SMP Negeri 11 Semarang Tahun Pelajaran 2005/2006 juga menunjukkan adanya peningkatan setelah dilakukan layanan bimbingan kelompok.

\section{SIMPULAN DAN SARAN}

\section{Simpulan}

Dari hasil uji hipotesis dapat disimpulkan bahwa ada peningkatan yang signifikan perilaku asertif melalui layanan bimbingan kelompok siswa kelas X SMA Kartika III-1 Banyubiru. Hal ini dibuktikan dengan hasil uji beda dengan Mann Whitney menunjukkan $\mathrm{Z}=-2,817$ dan Asymp. Sign. 2-tailed sebesar $0,005<0,050$ yang artinya perbedaan yang signifikan perilaku asertif kelompok eksperimen dan kelompok kontrol. Peningkatan perilaku asertif kelompok eksperimen dapat dilihat dari peningkatan rerata skor sebelum dan sesudah perlakuan pada kelompok eksperimen. Mean rank pre test kelompok eksperimen sebesar 6,00 dan mean rank posttest kelompok eksperimen sebesar 9,42, dengan demikian mean rank kelompok eksperimen meningkat sebesar 3,42.

\section{Saran}

Berdasarkan hasil penelitian yang dilakukan peneliti pada siswa kelas X SMA Kartika III-1 Banyubiru mengajukan saran sebagai berikut: 
a. Bagi Pihak Sekolah

Bagi para guru diharapkan untuk memperhatikan seluruh siswanya yang memungkinkan kurang asertif sehingga dilakukan upaya untuk meningkatkan perilaku asertif siswa.

b. Bagi guru BK

Bagi guru BK diharapkan untuk memahami perilaku asertif siswa melalui penyebaran instrumen. Selanjutnya apabila diketahui perilaku asertifnya masih sedang, rendah dan sangat rendah dapat membantu meningkatkannya melalui bimbingan kelompok.

c. Bagi Penelitian Selanjutnya.

Bagi peneliti selanjutnya yang tertarik dengan penelitian yang berkaitan dengan perilaku asertif dapat dijadikan acuan dan dapat menggunakan teknik bimbingan kelompok yang lebih bervariasi.

d. Bagi Subjek Penelitian

Bagi subjek penelitian khususnya siswa kelas X SMA Kartika III-1 dan kelas XI dan XII pada umumnya hendaknya dapat berperilaku asertif. Hal ini dapat dilakukan dengan cara menolak sesuatu yang memang tidak berkenan dengan diri tanpa menyinggung orang lain maupun merugikan orang lain.

\section{DAFTAR PUSTAKA}

Astutik, Tri Nurmawati. 2005. Efektifitas Layanan Bimbingan Kelompok dalam Meningkatkan Keterbukan Diri Siswa Kelas II SMP Negeri 11 Semarang Tahun Pelajaran 2005/2006. UNNES: Skripsi. lib.unnes.ac.id/3406/. Diunduh pada 6 Agustus 2013, pukul 08.00.

Figraha, Ichda Satria Arrozy. 2012. Upaya Peningkatan Sikap Asertif Melalui Sosio-drama Pada Siswa Kelas X. 1 Administrasi Perkantoran SMK Sudirman 1 Wonogiri Tahun Ajaran 2011/
2012. Yogyakarta: Univesitas Negeri

Yogyakarta. http://eprints. uny.ac.id/ 8253/. Diunduh pada 6 Agustus 2013, pukul 09.00.

Gunarsa, Singgih D. 1992. Konseling dan Psikoterapi. Jakarta: PT BPK Gunung Mulia.

Nurihsan, Achmad Juntika. 2005. Strategi Layanan Bimbingan dan Konseling. Bandung: Refika Aditama.

Prayitno. 1992. Layanan Bimbingan dan Konseling Kelompok. Jakarta: PT Rineka Cipta.

1995. Layanan Bimbingan dan Konseling Kelompok: Dasar dan Teori. Jakarta: PT Rineka Cipta.

Rakos, Richard F.1991. Assertive Behaviour: Theory, Research, and Training. New York: Routledge London.

Romlah, Tatiek. 2001. Teori dan Praktek Bimbingan Kelompok. Universitas Negeri Malang.

Siampa. 2011. Hubungan Antara Konsep Diri dengan Perilaku Asertif Mahasiswa Etnis Toraja. Fakultas Psikologi. Universitas Kristen Satya Wacana: Salatiga. Tidak diterbitkan.

Sukardi, Dewa Ketut. 2007. Pengantar Pelaksanaan Program BK di Sekolah: Buku Panduan untuk Guru Pembimbing/Konselor di SMP/SMA/SMK dan Perguruan Tinggi. Bandung: PT Rineka Cipta.

Winkel dan Hastuti, Sri. 2006. Bimbingan dan Konseling di Institusi Pendidikan. Yogyakarta: Media Abadi. 